REGULAR ARTICLE

\title{
DEGRADATION OF AZO DYE AND ELECTRICITY GENERATION USING YEAST MEDIATED MICROBIAL FUEL CELL
}

Sarita Ramsaran Yadav ${ }^{l}$, Mangala Lakshmi Ragavan ${ }^{2}$, Sanjeeb Kumar Mandal ${ }^{3}$ and Nilanjana Das ${ }^{4 *}$

Address (es):

${ }^{1,2}$ Bioremediation Laboratory, School of Bio Sciences and Technology, Vellore Institute of Technology, Vellore-632014, India Tel: 91-416-2202478, Fax: 91-4162243092 .

*Corresponding author: nilanjana00@1ycos.com ; nilanjanamitra@vit.ac.in

\section{ABSTRACT}

In the present study, the efficiency of yeast mediated microbial fuel cell (MFC) was investigated towards degradation of Trypan blue (azo dye) and electricity generation. Five yeast strains viz. SC1, SC2, SCD1, SCD2 and SCD3 were isolated from different sources. The internal resistance of yeast isolates was tested using ferric oxide reduction method. To maximize the power density of $\mathrm{MFC}, \mathrm{NaCl}$ was added to the medium and $\mathrm{NaCl}$ tolerance of yeast strains was tested. Among the five isolates, SC1 and SCD2 showed maximum ferric oxide reduction and $\mathrm{NaCl}$ tolerance. Initially $5 \%$ of SC1 and SCD2 yeast culture were inoculated in wastewater containing azo dye $(100 \mu \mathrm{g} / \mathrm{ml})$ in a H-type MFC chamber and $250 \mathrm{ml}$ conical flask used as control. Increased growth of yeast strain in MFC chamber was noted compared to conical flask culture. The data of electricity generation was taken for 15 days and electricity generation was measured using multimeter. Maximum electricity generation was noted in SC1 $(950 \mathrm{mV})$ followed by SCD2 $(750 \mathrm{mV})$. In addition, SC1 could degrade azo dye more efficiently than SCD2. Therefore, it may be concluded thatSC1 yeast mediated MFC can be used as potential technology for electricity generation and degradation of azo dye in wastewater.

Keywords: Azo dye, Electricity generation, FTIR analysis, Microbial fuel cell, Optimization

\section{INTRODUCTION}

Microbial fuel cell (MFC) has gained a great attention towards its ability in generating electricity by enhancing biodegradation of contaminants (Zhang $\boldsymbol{e t}$ al., 2009). Several factors affect electricity generation such as $\mathrm{pH}$, dissolved oxygen concentration in the cathode compartment. The highest electricity was generated at pH-7 with $6 \mathrm{mg} / \mathrm{l} \mathrm{DO}$ supply (Gil et al., 2003). Due to external circuit to direct electron transfer in MFCs as a driving force, pollutant degradation could be effectively stimulated (Bond et a.,l 2002; Zhang et al., 2010). It has higher capability of degrading toxic chemical or dye present in wastewater or textile industry which is very harmful to human (Patade et al., 2016). Azo dye is the chemical dye being used largely for textile, paper painting industries and discharge toxic effluents which cause higher pollution to the environment (Jafari et al., 2013). This azo dye used for textile, paper painting, dying to clothes in many industries and discharge toxic effluent which cause higher pollution to the environment (Yueh et al., 2016). Due to this penetration of light become less and reduce activity of photosynthetic which leads to less production of oxygen in aqueous ecosystem. It also has adverse impact of chemical oxygen demand, biological oxygen demand (Saratale et al., 2009). Recently, decolorized intermediate(s) of azo dye(s) were found to act as electron shuttles in dye-bearing MFC to enhance the performance of simultaneous color removal and power generation (Chen et al., 2013). Anodic treatment process on azo dye treatment using single chambered MFC, would be more favorable than double chamber MFCs due to non-mixing contacting reactor scheme for operation (Miyahara et al., 2015). MFCs considered as higher salinity for production of power after adding $\mathrm{NaCl}$ to it, increases the density of internal resistance of anode system and gives enhanced power output (Kong et al., 2015). It showed 94\% degradation on acid orange 7 pollutants. In particular, Thung et al., (2015) applied a single-chamber up-flow membrane-less MFC for decolorization of Acid Orange 7 and proposed that both anode and cathode contribute to dye decolorization, with the latter breaking down azo bonds the received electrons and protons on its surface. Many species like Geobacter bemidjiensis, Jishengella sp. and Verrucosispora sp. reported for higher production of electricity from 200 to $954 \mathrm{mV}$ (Shaikh et al., 2016). Bacillus circulans NPP1 MFC showed 96\% methyl red decolorization and $859 \mathrm{mV}$ electricity generation in a two chambered microbial fuel cell (Huarachi-Olivera et al., 2018). Reports are scanty on yeast mediated microbial fuel cell.

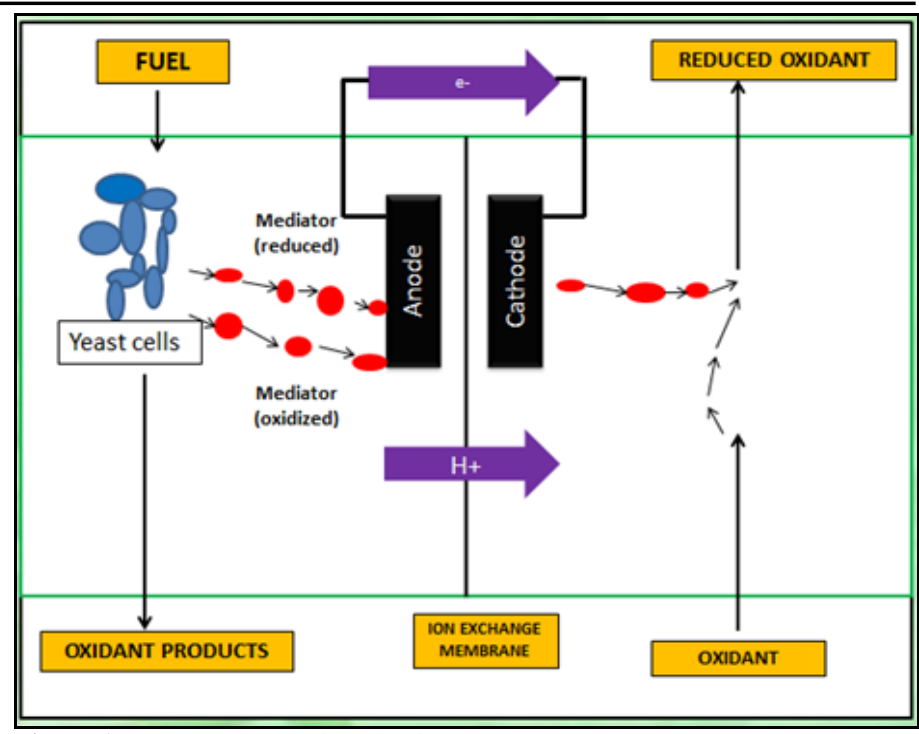

Figure 1 Yeast mediated microbial fuel cell

This study investigates the potential use of yeast mediated MFC for simultaneous electricity generation and treatment of textile effluent which is contaminated by trypan blue dye. Single chambered MFCs was used in this study and operated over three-batch cycles for 15 days (Figure 1).

\section{MATERIALS AND METHODS}

\section{Sample collection}

Sample of wastewater was collected from in and around vellore such as fresh cow dung, chicken, flower, millet root, sludge from VIT campus. Five yeast strains were isolated and screened for maximum electricity generation.

Chemicals

M9 media: $\mathrm{K}_{2} \mathrm{HPO}_{4} .2 \mathrm{H}_{2} \mathrm{O}(0.25 \mathrm{~g}), \mathrm{K}_{2} \mathrm{PO}_{4}(0.25 \mathrm{~g}), \mathrm{NaCl}(1.25 \mathrm{~g}),\left(\mathrm{NH}_{4}\right) 2 \mathrm{SO}_{4}$ $(0.075 \mathrm{~g}), \mathrm{MgSO}_{4} .7 \mathrm{H} 2 \mathrm{O}(0.075 \mathrm{~g}), \mathrm{CaCl}_{2}(0.005 \mathrm{~g})$. Trypan blue, ferric oxide, sodium thioglycollate, glucose, methylene blue, sulfuric acid, acetic acid, potassium iodide, sodium sulfite, ammonium chloride, dipotassium hydrogen phosphate, disodium hydrogen phosphate, calcium carbonate, magnesium 
sulfate, ferric chloride, phosphate buffer, sodium sulfate, starch solution, glucose (Herrero-Hernandez et al., 2013).

\section{$\mathrm{NaCl}$ tolerance}

Yeast isolates were inoculated on $100 \mathrm{ml}$ of $\mathrm{M} 9$ media which contains different concentrations of $\mathrm{NaCl}(0.05 \mathrm{M}-1.5 \mathrm{M})$ to increases internal resistance for electricity generation (Heijne et al., 2007). Incubated at $37^{\circ} \mathrm{C}$ for $24-48 \mathrm{~h}$. Blank media serves as a control. Samples were read at $600 \mathrm{~nm}$ using spectrophotometer.

\section{Ferric oxide reduction test}

Yeast isolates were inoculated on $100 \mathrm{ml}$ of M9 media with $0.1 \%$ ferric oxide and $0.1 \%$ sodium thioglycollate with or without $1 \%$ glucose. Incubated at $37^{\circ} \mathrm{C}$ for 24-48 h. Blank media serves as a control. Ferric oxide turns into black color indicates presence of ferric oxide reducing yeast (Ruggero Rossi, 2016).

\section{Respiration Test}

One $\mathrm{ml}$ of yeast isolates was mixed with $9 \mathrm{ml}$ of milk in a clean, sterilized test tube. To this $1 \mathrm{ml}$ of methylene blue was added and incubated on water bath at $37^{\circ} \mathrm{C}$ for $30 \mathrm{~min}$. After 30 mins its shows reduction in milk color (Akshay et al., 2016)

\section{Microbial fuel cell chamber}

Two plastic containers, each of $\sim 7-8 \mathrm{~cm}$ height and $8 \mathrm{~cm}$ breadth were taken to make the MFC design. Each container was filled with $3 / 4$ sterile soil and $1 / 4$ with yeast culture. The lid of the containers had 2 holes, one for anode and another for cathode. Kept as airtight container. Three different types of setup were made based on $\mathrm{NaCl}$ concentration $(1 \%, 2 \%$ and $3 \%)$. This setup was kept at $37^{\circ} \mathrm{C}$ with $\mathrm{pH} 7$ for 24-72 $\mathrm{h}$. Voltage and amperes was noted by using digital multimeter and plotted a graph for electricity generation (Patil et al., 2012).

\section{Degradation of trypan blue}

Selected yeast isolates were inoculated on $100 \mathrm{ml}$ trypan blue contaminated effluent and incubated at $37^{\circ} \mathrm{C}$ for $24-48 \mathrm{~h}$. Decolorization was noted by spectrophotometer at $600 \mathrm{~nm}$ and degradation was calculated by Jumma Shaikh et al (Heijne et al., 2007).

\section{RESULTS AND DISCUSSION}

\section{Preliminary Screening of isolated yeast}

Five yeast strains were isolated from different sources like fresh cow dung, chicken, millet root, waste water drainage. Yeast isolates were shown in Figure 2. Screening results reveals that $\mathrm{SC} 1$ and $\mathrm{SCD} 2$ has maximum tolerance against $3 \% \mathrm{NaCl}$ (Figure 3) and ferric oxide reduction (Figure 4) in M9 media.

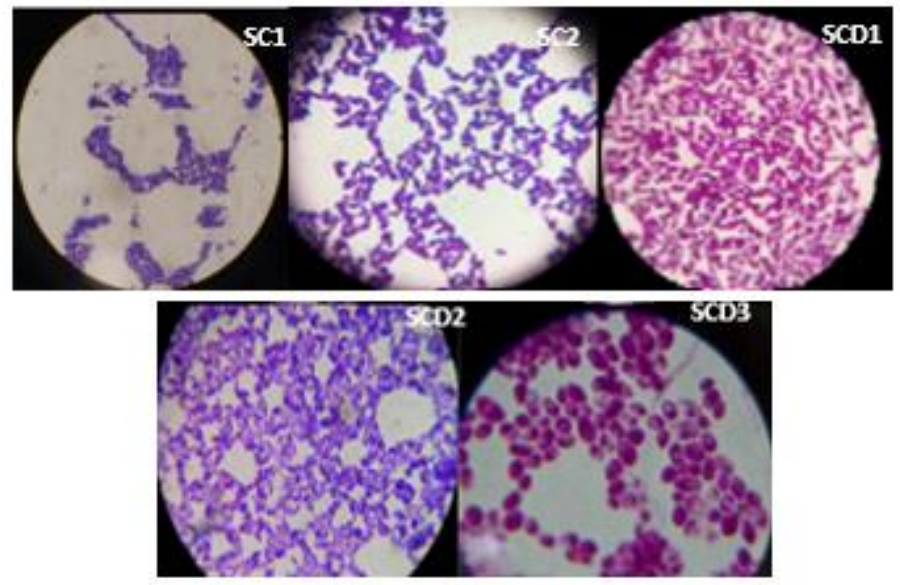

Figure 2 Microscopic images of yeast isolates

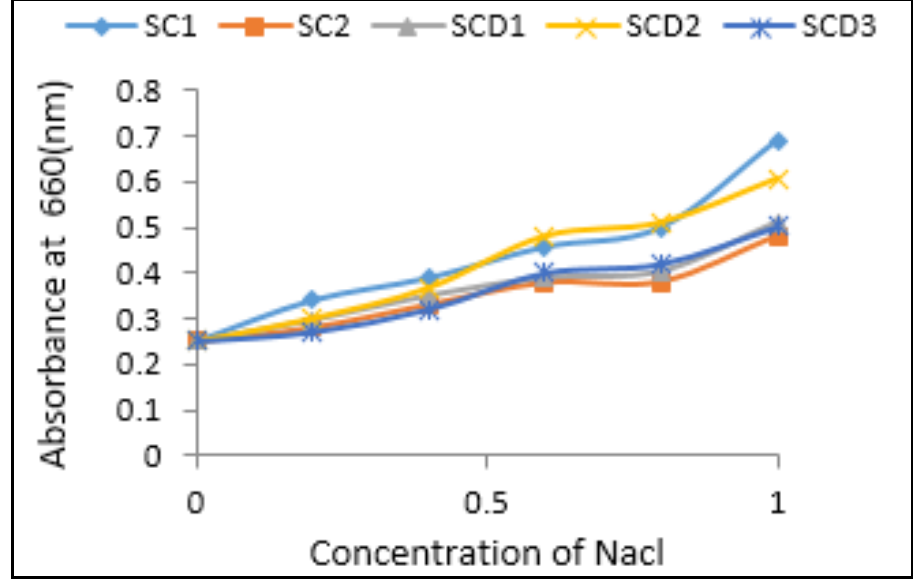

Figure $3 \mathrm{NaCl}$ tolerance

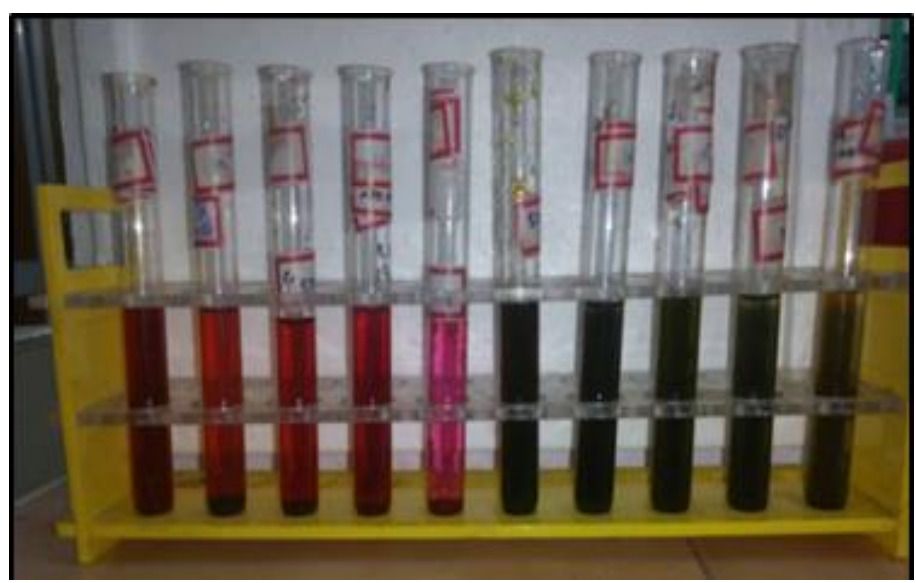

Figure 4 Ferric oxide reduction test

\section{Respiration test}

Respiration of selected yeast isolates were analyzed and results showed decoloration within 30mins (Figure 5). Faster respiration rate in microbes speeds up an electron transport system which leads to maximum electricity generation.

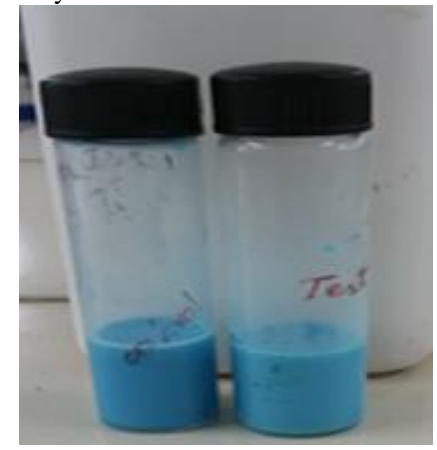

Figure 5 Respiration test

Electricity generation

MFC was designed for two isolates and initially electricity was measured for 15 days by using multivoltmeter. SC1 and SCD2 showed maximum electricity generation $720 \mathrm{mV}, 560 \mathrm{mV}$ on 7th day culture without trypan blue (Figure 6a). MFC chamber with trypan blue showed increased power density $820 \mathrm{mV}$ and $620 \mathrm{mV}$ for SC1, SCD2 respectively (Figure $6 \mathrm{~b}$ ). In both the case SC1 showed higher electricity generation compare to SCD2. 


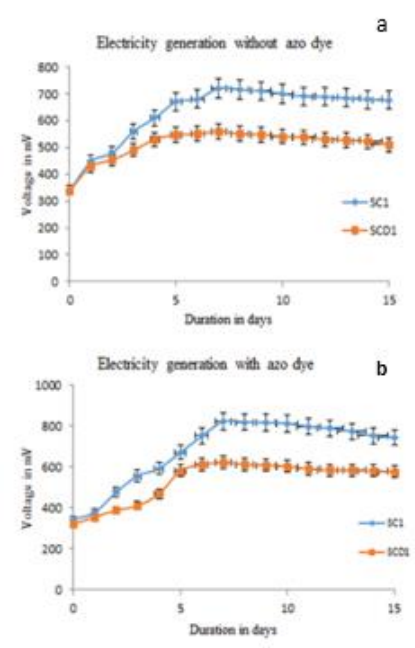

Figure 6 Electricity generation

\section{Electricity generation after dye treatment}

Electricity generation was taken by multivoltmeter after treating with trypan blue dye. SC1 showed increased electricity $(670-720 \mathrm{mv})$ than SC2 $(580-880 \mathrm{mv})$ on 7 th day and $15^{\text {th }}$ day respectively (Figure 7). Further SC1 was chosen for degradation studies.

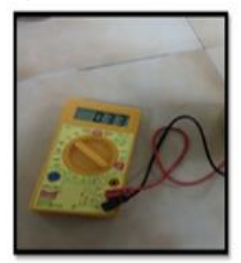

Initial reading on $0^{\text {th }}$ day (SC1)

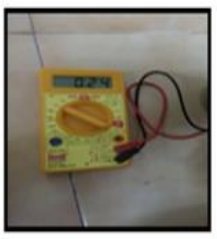

Initial reading on $\mathrm{O}^{\mathrm{a}}$ day $(\mathrm{SCO} 2)$

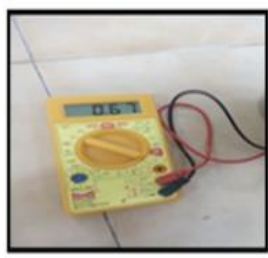

Reading on $7^{\text {th }}$ day (SC1)

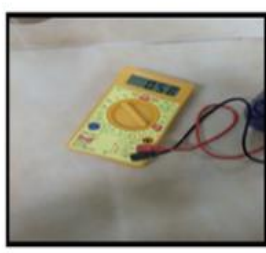

Reading on $7^{\text {th }}$ day $(\mathrm{SCD} 2)$

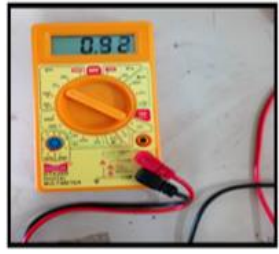

Final reading on $15^{\text {th }}$ day $(\mathrm{SC} 1)$

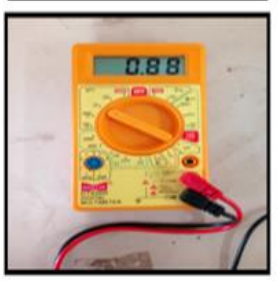

Final reading on $15^{\text {th }}$ day $(\mathrm{SCO} 2)$

Figure 7 Electricity generation by multivoltmeter using MFC

\section{Decoloration of dye by MFC}

Maximum decoloration rate was achieved on $4^{\text {th }}$ day (Figure 8 ) and $6^{\text {th }}$ day (not shown) in SC1, SC2 respectively. MFC with trypan blue contaminated textile effluent showed $76 \%$ and $64 \%$ degradation rate in SC1, SCD2 respectively. Maximum degradation was achieved by yeast mediated MFC compared to conventional method (Figure 9).

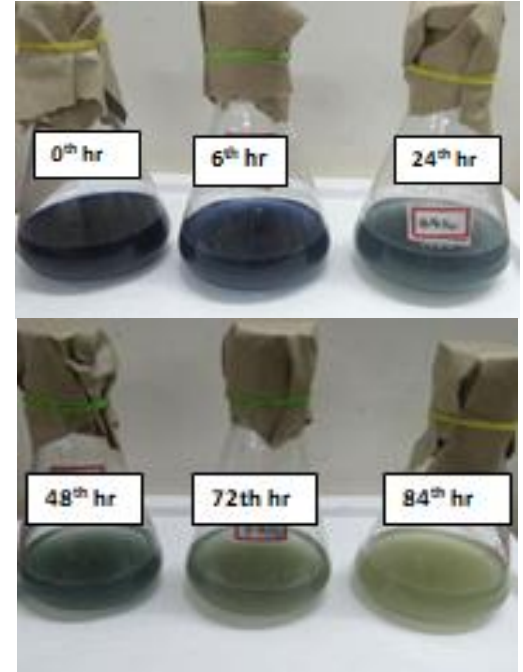

Figure 8 Decoloration of dye by MFC

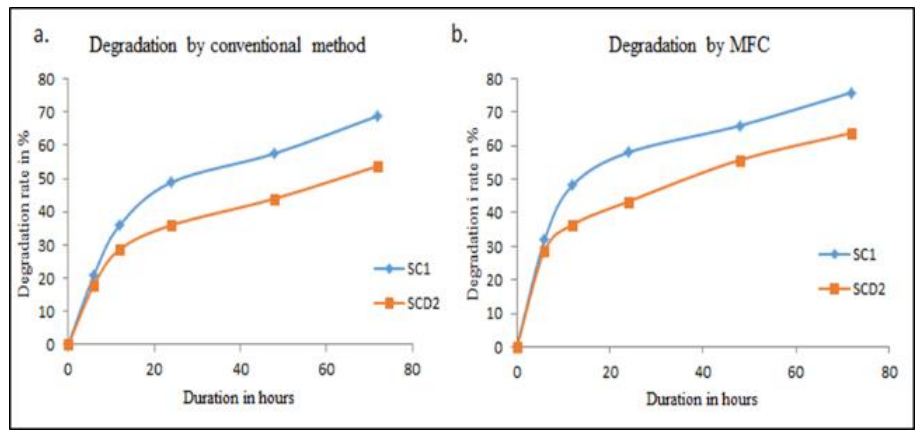

Figure 9 Degradation of dye by MFC in different time period

\section{FTIR Analysis of trypan blue}

FTIR analysis shows five different peaks of trypan blue without the sample and SC1 shows two peaks which indicates degardation of trypan blue at $3329.14 \mathrm{~cm}^{-1}$ alkanes group (O-H bond) and $1635.64 \mathrm{~cm}^{-1}$ (C-H bond). SCD2 shows peaks at $3331.07 \mathrm{~cm}^{-1}$ (O-H bond), $2768.20 \mathrm{~cm}^{-1}(\mathrm{C}-\mathrm{H}$ bond $)$ and $1635.64 \mathrm{~cm}^{-1}(\mathrm{~N}=\mathrm{N})$ which indicates partial degrdation of trypan blue ( Figure 10).

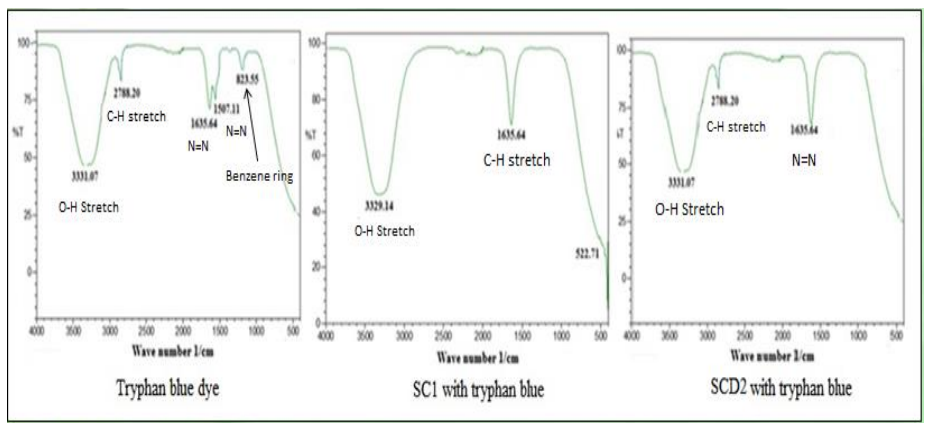

Figure 10 FTIR Analysis of trypan blue with two yeast isolates

\section{DISCUSSION}

In the present study, five yeasts were isolated from different sources and screened for ferric oxide reduction and $\mathrm{NaCl}$ tolerance to improve the quantity of electricity generation. Among the five isolates, SC1 and SCD 2 showed maximum electricity ( 720 and $880 \mathrm{mV}$ respectively) from a single container. The most interesting observation was that the setup could give almost same electricity output for nearly 10 days without adding anything. Further, yeast isolate SC1 and SCD2 chosen for trypan blue degradation in waste water. After treatment significant degradation of trypan blue was noted in MFC mediated degradation compared to conventional method of degradation. SC1 degraded trypan blue, azo dye more efficiently than SCD2. Therefore, it may be concluded that SC1 yeast mediated MFC can be used as potential technology for electricity generation and degradation of azo dyes in wastewater. 
Acknowledgement: Authors acknowledge VIT University for providing laboratory facilities.

\section{REFERENCES}

Akshay D. Tharali, Namrata Sain and W. Jabez Osborne. Microbial fuel cells in bioelectricity production. Frontiers in Life Science. 9(4); 2016:252-266. https://doi.org/10.1080/21553769.2016.1230787

Bond DR,Holmes DE,Tender LM and Lovley DR. Electrode-reducing microorganisms that harvest energy from marine sediments. Science. 295(5554); 2002: 483-5. https://doi.org/10.1126/science.1066771

Chen BY, Hong J, Ng IS, Wang YM, Liu SQ, Lin B, Ni C. Deciphering simultaneous bioelectricity generation and reductive decolorization using mixed-culture microbial fuel cells in salty media. Journal of the Taiwan Institute of Chemical Engineers. 44(3); 2013: 446-453. https://doi.org/10.1016/j.jtice.2012.12.003

Gil GC, Chang IS, Kim BH, Kim M and Jang JK, Park HS, Kim HJ. Operational parameters affecting the performance of a mediator-less microbial fuel cell. Biosensors and Bioelectronics.18(4);2003:327-334. https://doi.org/10.1016/S0956-5663(02)00110-0

Heijne AT, Hamelers HVM and Buisman CJN. Microbial fuel cell operation with continuous biological ferrous iron oxidation of the catholyte. Environmental Science and Technology. 41(11); 2007:41304134.https://doi.org/10.1021/es0702824

Herrero-Hernandez E, Smith TJ and Akid R. Electricity generation from wastewaters with starch as carbon source using a mediator less microbial fuel cell. Biosensors and Bioelectronics 39(1); 2013: 194-198. https://doi.org/10.1016/j.bios.2012.07.037

Huarachi-Olivera R, Dueñas-Gonza A, Yapo-Pari U, Vega P, Ugarte MR, Tapia J, Molina L, Lazarte-Rivera A, Pacheco-Salazar DG and Esparza M. Bioelectrogenesis with microbial fuel cells (MFCs) using the microalga Chlorella vulgaris and bacterial communities. Electronic Journal of Biotechnology.31;2018:34-43. https://doi.org/10.1016/j.ejbt.2017.10.013

Jafari N, Kasra-Kermanshahi R, and Soudi MR. Screening, identification and optimization of a yeast strain, Candida palmioleophila JKS4, capable of azo dye decolorization. Iranian Journal of Microbiology.5(4);2013:434-440.

Kong FY, Wang AJ and Ren HY. Optimized matching modes of bioelectrochemical module and anaerobic sludge in the integrated system for azo dye treatment. Bioresource Technology.192; 2015: 486493. https://doi.org/10.1016/j.biortech.2015.06.001

Miyahara M, Kouzuma A and Watanabe $\mathrm{K}$. Effects of $\mathrm{NaCl}$ concentration on anode microbes in microbial fuel cells. AMB Express.5; 2015. https://doi.org/10.1186/s13568-015-0123-6

Patade S, Silveira K, Babu A, D'costa F, Mhatre Y, Saini Y, Rajput R, Mathew J, Birmole R and Aruna K. Bioremediation of dye effluent waste through an optimized microbial fuel cell. International Journal of Advanced Research in Biological Sciences. 3(5); 2016:2348-8069. http://s-0i.org/1.15/ijarbs-2016-3-5-31

Patil. PN, Sawant. DV, Deshmukh. RN. Physico-chemical parameters for testing of water - A Review International Journal of Environmental Sciences. 3(3); 2012: 0976-4402.

Ruggero Rossi. Saccharomyces cerevisiae as anodic biocatalyst in microbial fuel cell: influence of redox mediator and operative conditions. Scientifico Disciplinare.11; 2016. http://doi.org/10.6092/unibo/amsdottorato/7911

Saratale RG, Saratale GD, Parshetti GK, Chang JS and Govindwar SP. Outlook of bacterial decolorization and degradation of azo dyes: a review. International Journal of Environmental Research and Public Health (2009) (communicated). https://doi.org/10.1016/j.jtice.2010.06.006

Shaikh J, Patil NP, Shinde V and Gaikwad VB. Simultaneous decolorization of methyl red and generation of electricity in microbial fuel cell by Bacillus circulans NPP1. Journal of Microbial and Biochemical Technology.8(5);2016:428-432. https://doi.org/10.4172/1948-5948.1000320 Thung WE, Ong SA, Ho LN, Wong YS, Ridwan F, Oon YL, Oon YS, Lehl HK. A highly efficient single chambered up-flow membrane-less microbial fuel cell for treatment of azo dye Acid Orange 7-containing wastewater. Bioresource Technology. 197; 2015:284-288. https://doi.org/10.1016/j.biortech.2015.08.078

Yueh PL, Chen BY, Hsueh CC. Unraveling biostimulation of decolorized mediators for microbial fuel cell-aided textile dye decontamination. International Science Index, Fashion and Textile Engineering.10(1); 2016.

Zhang C, Li M, Liu G, Luo H and Zhang R. Pyridine degradation in the microbial fuel cells. Journal of Hazardous Materials. 172 (1); 2009: 465471. https://doi.org/10.1016/j.jhazmat.2009.07.027

Zhang MM, Chen WM, Chen BY, Chang CT, Hsueh CC, Ding Y, Lin KL and $\mathrm{Xu} \mathrm{H}$. Comparative study on characteristics of azo dye decolorization by indigenous decolorizers. Bioresource Technology.101(8); 2010: 2651-2656. https://doi.org/10.1016/j.biortech.2009.10.070 